\title{
Effects of mountain gorilla foraging activities on the productivity of their food plant species
}

\author{
D. P. WATTS Department of Anthropology, The University of Michigan, Ann \\ Arbor, Michigan 48109, U.S.A.
}

\section{Summary}

Mountain gorillas subsist principally on foliage from the dense herbaceous understorey that is found throughout most of their habitat in the Virunga Volcanoes region. Their foraging activities cause considerable structural damage to this vegetation. Those plant species that are quantitatively most important in the gorillas' diet respond to this damage by increasing primary productivity. At a sample of spots at which gorillas had fed, these species showed significantly higher growth rates over a 6-month interval than they did at nearby spots that had not been touched by the gorillas. Stem densities of herbaceous food species at feeding spots increased markedly both in comparison to their original values and to values for the same species at untouched spots. As a result, spots at which gorillas have fed are likely to become very attractive as future feeding spots. It is unlikely that gorillas 'manage' their habitat in any specific fashion, largely because they do not have exclusive use of their home ranges. Their activities appear to maintain habitat productivity over the short term, on a time scale relevant to patterns of area revisits by social groups, and may contribute to long term beneficial alterations of regularly used areas, however. Effects of the type reported here may have been an important aspect of the adaptation by gorillas to terrestrial folivory.

\section{Résumé}

Les gorilles de montagne s'alimentent principalement de feuillages dans le sous-bois herbacé dense présent presque partout dans leur habitat de la région des volcans Virunga. Leurs activités alimentaires causent des dommages structurels considérables à cette végétation. Les plantes des espèces qui sont quantitativement les plus importants dans le régime du gorille réagissent à ces dégâts en augmentant leur productivité primaire. Aux postes échantillons où les gorilles se sont nourris, ces espèces présentent des taux de croissance significantivement supérieurs sur un intervalle de six mois, par rapport aux postes voisins qui n'ont pas été touchés par les gorilles. Les densités de tiges des espèces herbacées appétées aux postes de nourrissage augmentent nettement aussi bien en comparaison avec leurs valeurs antérieures qu'avec celles de ces mêmes espèces dans des stations non touchées. En conséquence, les postes où les gorilles se sont nourris ont plus de chance de devenir des futurs postes de nourrissage très attractifs. Il est peu probable que les gorilles 'gèrent' leur habitat d'une quelconque façon, surtout parce qu'ils n'ont pas l'utilisation exclusive de leur domaine vital. Leurs activités semblent maintenir à court 
terme la productivité de leur habitat, sur une échelle de temps comprenant les visites successives de groupes sociaux, et peuvent contribuer à long terme à des altérations bénéfiques pour ces zones régulièrement fréquentées. Des effets du type rapporté ici peuvent avoir été un élément important de l'adaptation des gorilles à la folivorie terrestre.

\section{Introduction}

Plants have evolved a complex array of chemical defenses against herbivory (Feeny, 1976; Rhoades \& Cates, 1976; Rosenthal \& Janzen, 1979; Fox, 1981) and have a variety of mechanisms to compensate for herbivore-induced structural damage and defoliation (McNaughton, 1977). Morphophysiological variation among plant species leads to variation in tolerance of herbivory, and the tolerance of a given species can vary in response to factors such as soil moisture and soil nitrogen content (McNaughton, 1977, 1980; Coughenor, McNaughton \& Wallace, $1985 \mathrm{a}, \mathrm{b})$. If herbivory exceeds tolerance limits, it can have a negative impact on plant productivity and population dynamics. This has been demonstrated in both natural situation (e.g. red deer browsing on saplings [Miller, Kinnaird \& Cummins, 1982] and hippo grazing on grasslands [Edroma, 1981]) and in simulations of herbivore damage (Coughenor et al., 1985b). However, foraging activities that do not pass this limit can ensure the renewal of herbivores' preferred resources and increase habitat productivity in some situations. Recent studies in the Serengeti have demonstrated that the grazing activity of migratory wildebeest prevents plant senescence and stimulates primary productivity along the western border of the plains. Moderate structural damage and defoliation due to wildebeest feeding initiates physiological processes, such as resource reallocation and the removal of apical dominance, which stimulate tissue productivity (McNaughton, 1976, 1977, 1980). This effect benefits both the wildebeest and migrating Thompson's gazelle. Similar effects also occur in other herbivore-plant systems (e.g., buffalo-grassland systems in other areas of Tanzania; Vessey-Fitzgerald, 1969, 1974).

Fossey \& Harcourt (1977) suggest that mountain gorillas, which are terrestrial folivores, exert a similar effect on their food supplies. Data gathered during a 17-month study of mountain gorilla feeding ecology in 1978-1979 in the Parc National des Volcans, Rwanda, and Parc des Virungas, Zaire, support this suggestion and show that gorilla-induced damage can increase the productivity of several important food species.

\section{Study site and methods}

The study site, in the central Virungas Volcano region, is an area of montaine rainforest. Average annual rainfall is about $1600 \mathrm{~mm}$. During the study period, the mean daily maximum temperature was $14.8^{\circ} \mathrm{C}$ and the mean daily minimum $3.8^{\circ} \mathrm{C}$. The vegetation cover is diverse, with most of the variability attributable to the effects of altitude (Spinage, 1972). A number of vegetation zones have been identified in the study area (Fossey \& Harcourt, 1977; Watts, 1984). There are quantitative and some qualitative differences among zones in plant species composition, but most are broadly similar in that they consist of Hagenia-Hypercium woodland with a relatively open canopy and extremely dense herbaceous understorey. The stem densities and frequencies (presence/absence at a given location) of several 
herbaceous species that contribute most of the gorillas' diet are high throughout most of this understorey (Watts, 1984). This combination of a relatively open canopy and dense herbaceous understorey characterizes the preferred habitat of gorillas throughout their geographic range (Schaller, 1963; Goodall, 1977; Tutin \& Fernandez, 1983).

I observed three social groups of gorillas (Karisoke groups 4, 5, and Nk). The majority of observations (about 1850) were of group 4. This group had a home range of about $9 \mathrm{~km}^{2}$ that extended in altitude from 2900 to $3700 \mathrm{~m}$. The group spent most of its time in areas of lush herbacious growth on the lower slopes of Mt. Visoke, referred to hereafter as the 'herbaceous slope' zone (35.4\% of time during the study period) and in an area at the north-west base of Visoke characterized by very abundant growth of the nettles Urtica massaica and Laportea alatipes (Urticaceae), referred to hereafter as the 'nettles' zone (16.7\% of time). These two zones were also used with relatively high intensity, where 'intensity' is defined as the percentage of study time spent in the zone divided by the percentage of the group's home range that consisted of that zone (Watts, 1983).

The gorillas were on the ground during $97 \%$ of their feeding time (Tuttle $\&$ Watts, 1985), and approximately $94 \%$ of their diet consisted of the leaves and stems of ground-level herbs, vines and shrubs (Watts, 1984). As they walk through the dense vegetation and while they rest, play, and sit to feed, the gorillas flatten many plant stems. While they feed, they typically sit on flattened stems and gather whole vines, strip or pick leaves from herbs, vines, or shrubs and break herbaceous stems. In this way, they break, bend and/or partially or wholly defoliate many plant stems. Heavily used areas look devastated and signs of gorilla use can persist for up to a year. However, the affected species soon begin to produce new stem and leaf growth and/or to produce new shoots vegetatively.

To assess the rate of regeneration and the effects of the gorillas on stem densities, I established sample plots in three areas where the gorillas had caused typical structural damage. Two of these were in herbaceous slope vegetation on the side of Mt. Visoke; the third was in the nettles zone. Area 1 (herbaceous slope), at $3200 \mathrm{~m}$, contained abundant growth of the herb Carduus nyassanus (Asteraceae) and the vine Galium ruwenzoriense (Rubiaceae) and moderately abundant L. alatipes. Area 2 (herbaceous slope), at $3125 \mathrm{~m}$, contained G. ruwenzoriense, L. alatipes, and abundant growth of the herb Peucedanum linderi (Apiaceae). Area 3 (nettles), at $3000 \mathrm{~m}$, was characterized by high densities of both species of nettles and abundant G. ruwenzoriense (Watts, 1984). Peucedanum linderi, L. alatipes and U. massaica are all herbs that grow to heights of 2-3 m. Very rarely, mountain gorillas eat the roots of these species, but they primarily use the stems of all three and the leaves of L. alatipes. Stem densities for all three can reach 30 or more per $\mathrm{m}^{2}$. Carduus nyassanus is also a herb that grows to heights of $3 \mathrm{~m}$. Unlike the previous three species, it often has multiple branched stems; it also has longer and broader leaves so that individual stems cover a larger area and stem densities are rarely more than 5 per $\mathrm{m}^{2}$. Galium ruwenzoriense is a vine that grows in dense tangles on herbaceous stems and on trees. This species list covers five of the quantitatively most important food plants in group 4's diet: together they contributed $84 \%$ of food intake (Watts, 1984).

In each area, I selected a total of twenty sample points (for a total of 60 points): ten where gorillas had been sitting and feeding (hereafter referred to as 'used' spots, 
and 10 points, each a random distance in a pre-selected direction from one of the used spots, that were untouched by gorillas. I chose used spots arbitrarily on the basis of a subjective evaluation of what looked like normal damage from feeding. I chose distances to control spots with the aid of a random numbers table: I chose a series of digits (zeros excluded) and, depending on the value of the digit associated with each used spot, walked from 1 to $9 \mathrm{~m}$ in the chosen direction to arrive at the control spot. If this spot had been used or had already been chosen as a sample spot, I proceeded a distance that corresponded to the next digit, and so on, until I arrived at an unused and unsampled spot. I noted the frequency of each food species and counted stem densities for herbaceous food species present within a circular area of one square meter that was centered on the point. I also estimated the above-ground biomass of each food species that was present. For herbs, I did this by measuring stem heights and inserting these into regression equations that had been computed independently from plants of known height that I had harvested and weighed. Height was a good predictor of biomass in each case $(r=0.93$, $\mathrm{df}=13, P<0.001$ for $L$. alatipes; $r=0.86, \mathrm{df}=10, P<0.01$ for $C$. nyassanus; $r=0.82, \mathrm{df}=11, P<0.01$ for $P$. linderi; $r=0.87, \mathrm{df}=17, P<0.001$ for $U$. massaica). For $G$. ruwenzoriense, I estimated biomass on the basis of estimates of the volume of stem and leaf present; these were made in terms of 'handfuls' (my own), with a standard value of $30 \mathrm{~g}$ per handful.

Because the gorillas did not remove whole plants, I could count stem densities at used spots for comparisons with those same spots at later times and with control spots.

Variance in stem densities tended to be high (Table 1). In fact, most mountain gorilla food species have significantly clumped distributions on the small scale of one square meter used here (Watts, 1983). Therefore, I used Wilcoxon matchedpairs signed-rank test (Snedacor \& Cochrane, 1967) to compare densities. In these analyses, each spot was paired with itself at the end of the study and with its associated control (or used) spot.

The initial sampling in each area was done on the day after the gorillas had passed through it. I repeated the measurements at approximately monthly intervals for the next 6 months.

\section{Results}

Table 1 shows estimated initial and final mean biomasses at used and at control spots in each sample area. Not surprisingly, initial biomasses at used spots were significantly lower than at control spots (Table 1) because the gorillas had just fed at the former. Subsequent food productivity was much higher at used spots. By the end of the study, mean biomasses at used spots were comparable to those at control spots in all three areas (Table 1), although regeneration appeared to be incomplete. There were no significant increases in mean biomass at control spots, whereas mean biomass increased substantially and significantly at used spots in all three areas (Table 1). For all food species combined, biomass at used spots increased at mean rates of $6.92 \mathrm{~g} \mathrm{~m}^{-2}$ day $^{-1}$ in area $1,9.92 \mathrm{~g} \mathrm{~m}^{-2}$ day $^{-1}$ in area 2 , and $4.71 \mathrm{~g} \mathrm{~m}^{-2} \mathrm{day}^{-1}$ in area 3 . Corresponding rates of increase at control spots were only $0.08 \mathrm{~g} \mathrm{~m}^{-2}$ day ${ }^{-1}, 0.09 \mathrm{~g} \mathrm{~m}^{-2}$ day $^{-1}$, and $0.06 \mathrm{~g} \mathrm{~m}^{-2}$ day $^{-1}$, respectively.

Galium ruwenzoriense contributed a relatively small proportion of total food biomass $(3 \cdot 2 \%, 1 \cdot 5 \%$ and $8 \cdot 5 \%$ of final biomass at used spots in areas 1,2 , and 3 , 
Table 1. Estimated mean initial and final biomasses $\left(\mathrm{g} \mathrm{m}^{-2}\right)$ of all food species combined at used and control spots

\begin{tabular}{lrrrr}
\hline Area & State & Initial biomass & Final biomass & \\
\hline 1 & Used & $531(98)$ & $1827(475)$ & $P<0.001$ \\
& Control & $2225(774)$ & $2239(810)$ & NS \\
& & $P<0.001$ & NS & \\
2 & Used & $643(314)$ & $2429(651)$ & $P<0.001$ \\
& Control & $2160(521)$ & $2178(646)$ & NS \\
& & $P<0.001$ & NS & \\
3 & Used & $459(170)$ & $1307(470)$ & $P<0.001$ \\
& Control & $1551(391)$ & $1564(545)$ & NS \\
& & $P<0.001$ & NS & \\
\hline
\end{tabular}

Value in parentheses equals one standard deviation. Results of $t$-tests comparing mean initial biomass at used $v$. control spots and mean final biomass at used $v$. control spots are given in the appropriate column; those from $t$-tests comparing mean initial $v$. mean final biomass at used spots and at control spots are given in the appropriate row.

respectively, for example; these figures are representative of group 4's home range as a whole [Watts, 1984]). It accounted for $35.7 \%$ of group 4 's diet and was quantitatively the most important food species for all study groups (Watts, 1984; cf. Fossey \& Harcourt, 1977). It is thus of particular interest that its growth rate at used spots $\left(0.41 \mathrm{~g} \mathrm{~m}^{-2} \mathrm{day}^{-1}\right)$ was over twice that at those control spots at which it occurred $\left(0.18 \mathrm{~g} \mathrm{~m}^{-2} \mathrm{day}^{-1}\right)$.

As the figures for $G$. ruwenzoriense indicate, differences in productivity were more complicated than is apparent from simple comparison of total initial and final biomass. Stem mortality balanced or exceeded the production of new growth at many control spots, but production of new growth exceeded losses due to stem mortality at all used spots. This is apparent from comparison of the proportion of biomass that was new growth ( $\leqslant 6$ months old): for used spots, these values were $70.1 \%$ in area $1,70.8 \%$ in area 2 , and $78.6 \%$ in area 3 ; corresponding values for control spots were $11 \cdot 3 \%, 11 \cdot 6 \%$ and $13.0 \%$.

A good estimate of the amount of error introduced by using stem height, rather than some more direct measure, to estimate biomass is not available. Any such error is unlikely to have been sufficient to account for differences of nearly an order of magnitude, however.

Table 2 shows initial and final stem densities in six cases where the same food species was present at both used and control spots at one of the sample areas. The table also gives results of Wilcoxon matched-pairs signed-rank tests for each comparison. (Galium ruwenzoriense was omitted from this analysis because it was too difficult to count its stem density.)

There was little difference between used and control spots in the initial stem densities of food species. The only significant difference is that there were more $U$. massaica stems at control spots in area $3(P<0.05)$; many of these stems were older and taller $(>1.5 \mathrm{~m})$ than those eaten by gorillas, however. 
Table 2. Initial and final mean stem densities (stems $\mathrm{m}^{-2}$ ) at sample spots

\begin{tabular}{|c|c|c|c|c|c|}
\hline Area & Species & State & Initial & Final & \\
\hline 1 & Laportea alatipes & $\begin{array}{r}\text { Used } \\
\text { Control } \\
\text { Used } \\
\text { Control }\end{array}$ & $\begin{array}{r}2.50(1.08) \\
2.00(1.41) \\
\mathrm{NS} \\
1.60(1.43) \\
2.40(1.71) \\
\mathrm{NS}\end{array}$ & $\begin{array}{r}3.00(0.82) \\
1.90(1.37) \\
P<0.05 \\
3.90(3.73) \\
3.10(2.42) \\
\text { NS }\end{array}$ & $\begin{array}{r}P<0.05 \\
\text { NS } \\
\\
P<0.05 \\
\text { NS }\end{array}$ \\
\hline 2 & $\begin{array}{c}\text { Peucedanum linderi } \\
\text { Laportea alatipes }\end{array}$ & $\begin{array}{r}\text { Used } \\
\text { Control } \\
\text { Used } \\
\text { Control }\end{array}$ & $\begin{array}{r}10.30(2.91) \\
9.40(4.09) \\
\mathrm{NS} \\
3.80(2.70) \\
6.00(3.50) \\
\mathrm{NS}\end{array}$ & $\begin{array}{r}17.10(2.95) \\
10.20(3.91) \\
P<0.01 \\
7.50(3.44) \\
6.70(2.26) \\
\text { NS }\end{array}$ & $\begin{array}{r}P<0.01 \\
\text { NS } \\
\text { NS } \\
P<0.01 \\
\text { NS }\end{array}$ \\
\hline 3 & Urtica massaica & $\begin{array}{r}\text { Used } \\
\text { Control } \\
\text { Used } \\
\text { Control }\end{array}$ & $\begin{array}{r}8.50(5.21) \\
13.40(5.15) \\
P<0.05 \\
1.80(2.36) \\
3.20(2.97) \\
\text { NS }\end{array}$ & $\begin{array}{r}19.80(6.83) \\
15.80(6.88) \\
\mathrm{NS} \\
5.80(7.75) \\
5.40(5.87) \\
\mathrm{NS}\end{array}$ & $\begin{array}{r}P<0.01 \\
\text { NS }\end{array}$ \\
\hline
\end{tabular}

Value in parentheses equals one standard deviation. Results of Wilcoxon matched-pairs signed-rank tests comparing mean initial density at used $v$. control spots, and mean final density at used $v$. control spots given in appropriate column; results from comparisons of initial and final densities at used spots and at control spots given in appropriate row.

The ratio of mean density at used spots to mean density at control spots increased over the 6-month interval in every case (Table 2). By the end of the study, mean density was higher at used spots than at control spots in all six cases (initial density had been higher at control spots in four cases), and the difference was significant for $C$. nyassanus in area 1 and $P$. linderi in area 2.

Comparisons of initial and final stem densities at used spots alone reveal significant increases during the 6-month interval in all six cases (Table 2). Increases were particularly marked for $P$. linderi in area 2, U. massaica in area 3, and L. alatipes in areas 2 and 3 . The density of $C$. nyassanus in area 1 increased significantly, but the increase was small in absolute terms. It would be interesting to know if the gorillas can have a pruning effect that leads to increased branching by these thistles, but this was not measured. At control spots, conversely, there were no significant increases in stem density during the study (Table 2 ).

Data on group 4's patterns of revisits to areas within their home range (Watts, 1983) indicate that changes in food species productivity that occurred over a 6-month interval could have been relevant to habitat use decisions. The standard topographic map of the study area is divided into quadrats $250 \mathrm{~m}$ on a side. Group 4's median return to quadrats that contained mostly or only herbaceous slope vegetation was $\mathbf{4 0}$ days; the median return time to those that contained mostly or only nettle vegetation was 55 days. These figures are deceptively low in relation to regeneration times because they are based only on quadrat entrances and do not measure revisits to specific smaller areas, on the order of $25 \times 25 \mathrm{~m}$ (about the size 
of the regeneration study areas discussed here). If the group recrossed its exact path only on every third or fourth revisit, it would have arrived at previously used spots that were about at the stage of regeneration described here. It should also be noted that the area through which a group moves on a given day is not uniformly disturbed, and much of the vegetation is not touched at all. I have little data on revisits to specific small areas, but it is of interest that area 1 was re-used 125 days after the start of the study (without disturbance to any of the sample spots) and that sample spots had been revisited and disturbed in all three areas within 8 months of the start of the study.

\section{Discussion}

When a mountain gorilla forages in a given area within its home range, the effects of its behaviour on the vegetation there have certain consequences for its subsequent foraging decisions. An immediate effect is to depress resource availability, and it would not pay the animal to revisit the same feeding spots, and perhaps even the same general location, a day or a week later because resource renewal is slow. The data given above indicate that those spots would tend to become highly attractive feeding spots after several months, however, and that revisits would be worthwhile. A gorilla who returned after 6 months would find, for at least several of its most important food species, that average stem densities at used spots were now considerably higher than they had been 6 months previously. Stem densities at these spots also would have increased, on average, relative to spots that had not been touched 6 months previously. Probably more important, food productivity would have been higher at previously used spots than at untouched spots, and these would now contain abundant young growth of high quality foods. It is likely that it is nutritionally advantageous for the gorillas to eat young growth, although this remains to be demonstrated. This would be consistent with patterns of selective feeding that provide them with a diet of high quality (Watts, 1983; D. P. Watts, A. L. Vedder and P. G. W. Waterman, in prep.).

The existence of these effects on habitat productivity implies that gorilla foraging actually can increase average habitat quality on a time scale relevant to the gorillas' movement patterns. The overall effect is similar to that described for ungulates in the Serengeti and elsewhere (Vesey-Fitzgerald, 1969, 1974; McNaughton, 1976, 1977, 1980), although the mechanisms involved in the response of vegetation to gorilla damage have not been analysed. Because much of the gorillas' feeding involves tearing off or breaking plant stems, the removal of apical dominance is likely to be of importance in this case. It seems likely that the removal of overshading and the creation of miniature light gaps in the dense herbaceous understorey is also important, as can be analogously the case in herbivore-grassland systems (McNaughton, 1977; Coughenor et al., 1985b).

Gorilla-induced improvement in food productivity must have an upper limit, however, and possibly it happens only on a relatively short time scale. If used spots are not re-used after 6-8 months, competition between and among plant species will curtail their growth and lead to increased stem mortality. Both growth rates and stem densities would probably ultimately converge to their original values and/or to the habitat mean. Food species that are not rapidly regenerating herbs or vines (e.g., the arborescent shrubs Vernonia adolfifredericii and Senecio johnstonii) 
quite likely respond less efficiently to herbivory by gorillas. Also, damage produced by gorilla foraging may make some herbaceous species more susceptible to damage by occasional nocturnal frosts.

Nevertheless, the question arises as to whether the gorillas may actually 'manage' their habitat by consistently re-using certain spots so as to keep productivity of desired resources high there. Such an effect would not have to be specific to feeding: as noted above, other activities also damage the vegetation, and it looked like the response of plants to these activities was qualitatively similar to the response induced by feeding (although not necessarily quantitatively the same). Thus, for example, an area with a high density of 2-m tall $U$. massaica stems that was not attractive as a feeding spot could have been rendered more attractive (after several months) by gorillas as they played or as they walked through it to arrive at a more attractive spot. It should be noted, however, that the gorillas' effect on non-food species is unknown, and non-food species are also damaged by activities other than feeding. There is a more important reason why detailed habitat 'management' would be difficult to achieve, however. Home range overlap between groups is extensive and can approach $100 \%$. Group 4 shared $70 \%$ of its home range with other social units (groups and solitary males), and much of the overlap area was used heavily by one other group. Different groups may independently visit the same area at intervals that are less than optimal for food species regeneration. Any ability to adjust revisit rates would be imperfect because of the impossibility of predicting the movement patterns of other groups (except on those relatively rare occasions when social units are in auditory and/or visual contact).

What may result rather than a 'managed' microhabitat is a highly complex and constantly shifting mosaic of small areas that vary in their attractiveness to gorillas. The dynamics of this mosaic could also be affected by the activities of the other large herbivores in the Virungas (elephant, buffalo, bushbuck, duiker) as well as by the effects of competition among plants, plant senescence, etc. Regular use of particular areas by gorillas over prolonged periods might maintain these areas as highly attractive habitat even if home range overlap makes close management impossible over the short term. Whether any of the gorillas' food species depend on them for competitive success, as is true of obligate grazophiles and the ungulates which consume them in the Serengeti (McNaughton, 1977), is unknown.

Data on the regeneration patterns and demography of several herb species used heavily as food by western gorillas in Cameroon concur with results reported here (Bullock, 1978, 1981). This suggests that the positive effect on the productivity of favoured food species described here may occur commonly throughout the geographic range of gorillas.

\section{Acknowledgments}

I thank the Director and Staff of L'Office Rwandaise du Tourisme et des Parcs Nationaux for permission to do research in Le Parc National des Volcans. I thank Diane Fossey and the National Geographic Society for permission to use the facilities of the Karisoke Research Centre and Diane for helping to provide me with the opportunity to study mountain gorillas. The research presented here and many of 
the ideas that went into it were developed in discussions with Amy Vedder. Stuart Altmann, Robin Foster, A. H. Harcourt, Richard Klein, Doug Schemske, Russel Tuttle, and Richard Wrangham provided helpful criticism of earlier versions of the manuscript. Rwelekana Emmanuel and Nemeye Alfonse provided invaluable field assistance. Fieldwork was funded by NIMH grant MH 5 T32 15181-03.

\section{References}

BuLlOCK, S.H. (1978) Regeneration of Musa after feeding by Gorilla. Biotropica 10, 309.

Bullock, S.H. (1981) Dynamics of vegetative shoots of three species of Afromamum (Zingiberaceae) in Cameroon. Adansonia (2), 20, 383-392.

Coughenor, M.B., MCNaughton, S.J. \& Wallace, L.L. (1985a) Responses of an African tall grass (Hyparrhenia filipendula Stapf.) to defoliation and limitations of water and nitrogen. Oecologia 68, $80-86$.

Coughenor, M.B., MCNaughton, S.J. \& Wallace, L.L. (1985b) Responses of an African graminoid (Themeda triandra) to frequent defoliation, nitrogen, and water: a limit of adaptation to herbivory. Oecologia 68, 105-110.

Enroma, E.L. (1981) Some effects of grazing on the productivity of grassland in Rwenzori National Park, Uganda. Afr. J. Ecol. 19, 313-326.

Feeny, P. (1976) Plant apparency and chemical defense. Rec. Adv. Phytochem. 10, 1-40.

Fossey, D. \& HARCoURT, A.H. (1977) Feeding ecology of free-ranging mountain gorillas. In: Primate Ecology. (Ed. T.H. Clutton-Brock). Academic Press, London.

Fox, L.R. (1981) Defense and dynamics in plant-herbivore systems. Am. Zool. 21, 853-864.

GOODALL, A. (1977) Feeding and ranging behaviour of a mountain gorilla group (Gorilla gorilla beringei) in the Tshibinda-Kahuzi region (Zaire). In: Primate Ecology. (Ed. T.H. Clutton-Brock). Academic Press, London.

MCNAUGHTON, S.J. (1976) Serengeti wildebeest: facilitation of energy flow by grazing. Science 193, 92-94.

MCNaughroN, S.J. (1977) Grazing as an optimization process: grassland-ungulate relationships in the Serengeti. Am. Nat. 113, 691-703.

MCNaughton, S.J. (1980) Grassland-ungulate dynamics. In: Serengeti: Dynamics of an Ecosystem. (Eds A.R.E. Sinclair \& M. Norton-Griffiths). University of Chicago Press, Chicago.

Miller, G.R., KINNAIRD, J.W. \& Cummins, R.P. (1982) Liability of saplings to browsing on a red deer range in the Scottish highlands. J. appl. Ecol. 19,941-95I.

RhoADES, D. \& CATES, R. (1976) Towards a general theory of plant anti-herbivore chemistry. Rec. Adv. Phytochem. 10, 168-213.

Rosenthal, G.A. \& Janzen, D.H. (1979) Herbivores: Their Interaction With Plant Secondary Metabolites. Academic Press, New York.

SChaller, G. (1963) The Moutain Gorilla. University of Chicago Press, Chicago.

SNedecor, G.W. \& Cochran, W.G. (1967) Statistical Methods. Iowa State University Press, Ames, Iowa.

SPINaGE, C. (1972) The ecology and problems of the Volcano National Park, Rwanda. Biol. Conserv. 4, 194-204.

Tutin, C. \& Fernandez, M. (1983) Recensement des Gorilles et des Chimpanzes du Gabon. Centre Internationale de Recherches Medicales de Franceville (C.I.R.M.F.). Franceville, Gabon.

TutTLE, R.H. \& WATTS, D.P. (1985) The positional behaviour and adaptive complexes of Pan gorilla. In: Primate Locomotion and Bipedalism. (Eds S. Kondo, H. Ishida, M. Okada, T. Kimura \& M. Yamazaki). Tokyo University Press, Tokyo.

Vesey-FitzGerald, D.F. (1969) Utilization of the habitat by buffalo in the Lake Manyara National Park. $E$. Afr. Wildl. J. 7, 131-145.

VeSEY-FitzGeraLD, D.F. (1974) Utilization of the grazing resources by buffalo in the Arusha National Park, Tanzania. E. Afr. Wildl. J. 12, 107-134.

WatTS, D.P. (1983) Foraging Strategy and Socioecology of Mountain Gorillas. Ph.D. Thesis, University of Chicago.

WATTS, D.P. (1984) Composition and variability of mountain gorilla diets in the central Virungas. Am. $J$. Primatol. 7, 323-356. 